\title{
The Review of Methods for Debris Flow Hazard
}

\author{
Assessment \\ Hui Gao ${ }^{1,2}$, Jifu Liu ${ }^{1,2^{*}}$ \\ ${ }^{1}$ Key Laboratory of Environmental Change and Natural Disaster of Ministry of Education, Beijing Normal \\ University, Beijing 100875, China \\ ${ }^{2}$ Academy of Disaster Reduction and Emergency Management, Ministry of Civil Affairs \& Ministry of Education, \\ Beijing Normal University, Beijing 100875, China
}

\section{泥石流危险性评价方法研究综述}

\author{
高慧 ${ }^{1,2}$, 刘吉夫 ${ }^{1,2 *}$ \\ ${ }^{1}$ 环境演变与自然灾害教育部重点实验室, 北京师范大学, 北京 100875 , 中国 \\ 2 民政部/教育部减灾与应急管理研究院, 北京师范大学, 北京 100875 , 中国
}

\begin{abstract}
China is one of the countries which are suffering the most serious debris flows. The social life and economy in the mountain area are suffering a lot from them. With the frequency of debris flow increases in recent years, the threat to human life and property is bigger and bigger. Especially the seismic areas have suffered serious debris flows after the "5.12" Wenchuan Earthquake,. And the disasters may last for decades. With the promulgation of "To speed up the development of modern insurance services" in 2014, the demands for debris flow insurance put forward, and the requirements for accuracy and scientificalness of debris flow hazard assessment is higher. So debris flow hazard assessment of is more important and urgent now. This paper reviews the development history of debris flow and the research status of debris flow hazard assessment in China. And introduce three kinds of hazard assessment methods in China: based on the statistical evaluation, numerical simulation and $3 \mathrm{~S}$ technology. Then discuss the possible development trend of hazard assessment of debris flow.
\end{abstract}

基金项目: 国家科技支撑计划项目（2012BAK10B03）; 中 央高校基本科研业务费专项资金资助 *通讯作者: liujifu@bnu.edu.cn
Keywords: debris flow; hazard assessment; statistical methods; numerical simulation; $3 \mathrm{~S}$ technology

\section{摘要}

我国是泥石流灾害最严重的国家之一, 泥石流灾害严 重影响着山区人们的社会经济生活。近年来泥石流灾 害发生频率增大, 泥石流对于生命财产的威胁越来越 大。特别是 “ 5.12 ” 汶川特大地震发生后, 震区泥石 流灾害严重, 影响时间可能长达数十年。随着 2014 年我国 “关于加快发展现代保险服务业的若干意见” 的颁布, 对于泥石流巨灾保险的需求提上了日程, 对 泥石流危险性评价的准确性和科学性提出了更高的 要求, 危险性评价研究更为重要和紧迫。本文梳理了 国内外泥石流研究的发展历程和泥石流危险性评价 研究现状, 重点介绍三类泥石流危险性评价方法: 基 于统计学、基于数值模拟和结合 $3 \mathrm{~S}$ 等技术的泥石流 危险性评价方法, 进而对泥石流危险性评价方法的发 展趋势进行讨论。

关键词: 泥石流; 危险性评价; 统计方法; 数值 模拟； $3 \mathrm{~S}$ 技术

1 引言

我国山区面积广大, 地形复杂多变, 季风气候显著, 地震活动频发、断裂构造发育, 为泥石流提供了有利 


\section{Risk Analysis and Crisis Response in Big Data Era (RAC-16)}

的形成发育条件, 我国成为世界上泥石流分布最广、 数量最多、危害最重的国家之一。据相关统计, 在全 国 31 个省市自治区中, 29 个省、自治区、直辖市, 771 个县 (市) 有泥石流活动, 140 多座城镇建设在 泥石流堆积区上; 全国有灾害性泥石流沟谷 8500 多 条, 泥石流分布面积占国土面积的 18.6\%左右[2]; 20 世纪末期的几十年里, 泥石流灾害平均每年造成近千 人死亡, 每年直接经济损失达 10 亿多元[3]。

国内外有很多泥石流危险性评价的方法, 在防灾 减灾方面发挥的效益得到了实践的检验。但在全球气 候变暖的大环境下, 随着人类社会经济活动的增强, 泥石流灾害发生的频率显著增大, 泥石流对人民生命 财产的威胁也越来越大, 尤其是经历了 2008 年汶川 特大地震后, 破碎的山体和松散、充足的崩塌滑坡物 质, 在强降雨的激发下, 极易爆发泥石流灾害 [4], 在震后的 5-10 年[5], 甚至长达 30 年 [6, 7]的时间里, 震区泥石流危险性较大。在泥石流灾害频发的区域, 存在一些治理工程的失效或者被破坏的情况[8]（图 1), 甚至有些防护工程在泥石流的冲击下成为致灾因 子而加剧破坏的程度, 如 “ $8 \cdot 7$ ” 甘肃舟曲特大泥石 流中上游的暴雨形成的洪水将舟曲三眼峪沟和罗家 峪沟内的天然堆石坝和人工拦挡坝冲垮, 形成规模巨 大、危害性巨大的灾害性泥石流, 冲毁房屋 5500 余 间, 造成 1744 人死亡和失踪[9], 说明泥石流危险性 评价结果的科学性和准确性对于设计防治工程的重 要意义。2014 年 8 月 13 日保险业 “关于加快发展现 代保险服务业的若干意见” 的颁布[10], 对于泥石流 等巨灾保险建立的需求提上了日程, 这对于泥石流危 险性评价的定量化、准确性和科学性的要求加大, 泥 石流危险性评价方法的研究更为紧迫和重要。

唐邦兴、杜榕恒等在 20 世纪 90 年代都做过泥石 流研究的综述, 对泥石流危险性研究进展进行了梳理 $[11,12]$ 。本文在此基础上, 加之大量阅读近些年的 参考文献, 梳理国内外泥石流危险性评价研究的发展 历程, 总结现有的泥石流危险性评价方法, 旨在分析
每种方法的优缺点, 为科学、准确地评价泥石流的危 险性提供思路, 为预测泥石流灾害风险、编制城镇规 划、制定防灾减灾预案、开展泥石流巨灾保险等提供 理论依据。

\section{2 泥石流危险性评价研究概况}

泥石流危险性是指遭受泥石流损害的可能性大小, 损 害可能性的定性表达是危险性, 定量表达是危险度 [13]。危险性评价是目前的研究热点之一, 是在灾前 预防、灾后评估、救灾的等管理和决策中的基础。在 泥石流危险性研究方面, 国外时间不足200年, 国内 仅仅 40 余年。

在国外, 从17世纪开始, 随着人类活动范围的增 大, 欧洲阿尔卑斯山区的泥石流灾害加剧, 阿尔卑斯 山周边的国家和地区不断探索各种方法对泥石流进 行治理: 如利用边坡的治理、植被恢复以及各种水工 工程相结合的防范有效的控制泥石流的发展 [14], 并 提出了用红、黄、绿三个等级分别代表泥石流的危险 区、潜在危险区和无危险区。19世纪后半期俄国道路 工程师B.H.斯塔特夫斯基在设计山区公路时, 就涉及 到了泥石流的成因和泥石流危险度的问题[15]。1957 年M.A维利康诺夫等出版《泥石流及其防治法》一书, 介绍了其提出的粘性泥石流力学模型[16]。虽然泥石 流危险度的涉及较早, 但对危险性评价的定量化方法 直到 20 世纪晚期才开始。

在日本, 山地面积占国土面积的 $76 \%$, 多地震和 火山, 地震和火山导致的泥石流灾害频发。日本学者 足立胜治等选定地貌条件、泥石流形态特征和降雨这 3 个评价因子分析判定泥石流发生概率, 为泥石流危 险性评价奠定了基础[17]。池谷浩等根据流域面积与 冲出量的统计关系, 进而预测泥石流的危险范围, 是 较早从统计学角度出发的泥石流危险性评价 [18]。 1980年高桥堡和水山高久等从水力学的角度进行模 型试验, 出发探讨泥石流堆积过程和堆积范围 [19],
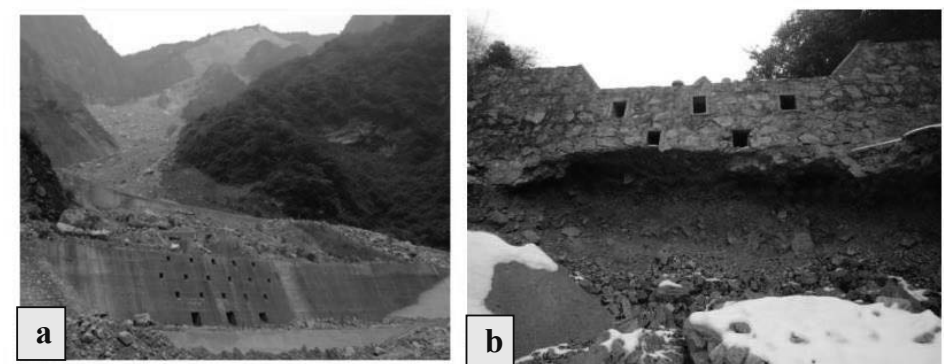

图 1 绵竹小岗剑上游防护工程（a）破坏情况和都江堰银洞子沟 1\#坝（b）（引自唐得胜, 2014） 
Risk Analysis and Crisis Response in Big Data Era (RAC-16)

1987年提出了预测泥石流危险范围的数学模型。

在美国, 20世纪初向西部山区移民的过程中, 遭 受到泥石流的严重危害, 开始了泥石流的治理研究: 1970年地质地貌学家Johnson和Rahn选用宾汉模型, 建立泥石流运动方程, 计算出了泥石流的最大流速, 这是第一篇关于泥石流运动模型的研究论文 [20]。 1981年美国地质工程师Hollingsworth和Kovacs采用 专家打分的方法, 以岩性、坡度和切割密度为 3 个评 价因子并进行分级, 通过因子叠加契合得出危险性评 价结果, 由此提出了泥石流危险度评价的框架[21], 这对后来泥石流危险性评价方法提供了较强的指导 意义, 目前很多研究方法都是基于因子叠加原理进行 的[22]。

国内泥石流危险性评价的研究始于 20 世纪 80 年 代, 虽起步晚但发展快。最早涉及泥石流危险性评价 研究的是1986年的谭炳炎[23], 通过选定地貌因素、 河沟因素和地质因素所包含的15项项目, 对每个项目 进行4级量化得分, 根据所有项目的得分总和评判泥 石流的严重程度。1988年, 以刘希林为代表, 发表“泥 石流危险度判定的研究”, 文中正式使用 “危险度” 一词, 将定性与定量分析相结合, 提出判定泥石流危 险度的计算模型[24]。

进入 20 世纪 90 年代以来, 随着各种数学理论的成 熟, 数学理论越来越多应用于危险性评价工作中, 其 中代表性的有模糊数学、灰色理论、数值模拟等方法, 同时，随着3S技术、无人机、红外、远红外等新技术 手段的提出和在泥石流危险性评价中的应用, 如通过 RS 获取灾害的相关数据, 减少野外的工作量, 利用 GIS 强大的空间分析功能和制图功能, 大大提高了泥 石流危险性评价的效率和精度。

总的来说, 经过多年发展, 泥石流危险性评价已 由传统的野外实地观测、勘探, 发展到逐步采用模型 试验和数值模拟, 从传统的定性描述和不完全统计分 析, 发展到半定量评价或定量评价, 评价体系也日益 完善和合理。

\section{3 泥石流危险性评价研究方法}

目前国内外进行泥石流危险性评价的方法很多, 主要 包括三类: 其一是从泥石流发育的背景要素和泥石流 活动状况的统计分析出发, 如选用发育的气象、地貌、 地质条件或者泥石流规模、频次等指标来统计评估泥 石流的危险性; 其二是从泥石流的运动机理和力学特 性出发, 泥石流运动模型、研究先进的数值解法, 开 发数值模拟软件, 从而进行泥石流危险性评价。其三 是在前面两类方法的基础上, 结合 $3 \mathrm{~S}$ 技术等进行泥石 流危险性评价。

\section{1 基于统计学的泥石流危险性评价}

从统计学角度出发的泥石流危险性评价方法较多, 如 灰色系统理论、模糊综合评判法、层次分析法、人工 神经网络法等, 这类方法的一般流程和模式为: 选取 评价因子、进行评价因子等级划分、构建评价模型, 最后得出危险性评价的结果 (图2)。基于统计学的泥 石流危险性评价方法较为主观, 因研究者的研究区 域、研究视角、资料的完备性等不同, 选取的评价因 子、评价因子分级、构建的评价模型都会有所不同, 得出的危险性评价结果也就不同。

\subsection{1 评价因子的选取及分级}

泥石流运动机理的复杂性及过程的可变性, 使得泥石 流灾害评价体系由多因子组成 [25], 据统计, 影响泥 石流发生、发展、运动和堆积过程中的环境背景因子 累计达70多种 [26], 国内对泥石流危险性评价因子的 选取问题, 一般从地形地貌、地质构造、水文气象、 植被条件、人为影响等五个方面来考虑。泥石流危险 性评价中对于评价因子的选取, 需要考虑评价因子的 科学性、正确性、全面性、代表性、简便性和实用性。 实际工作中, 因为计算的方便和精确, 一般对评价因 子划分 4-6级。典型研究中选取的评价因子如表 1 。

\subsection{2 构建评价模型}

选取评价因子后, 采用不同的数学方法确定因子的权 重和因子间的主次关系, 从而构造相应的数学模型,

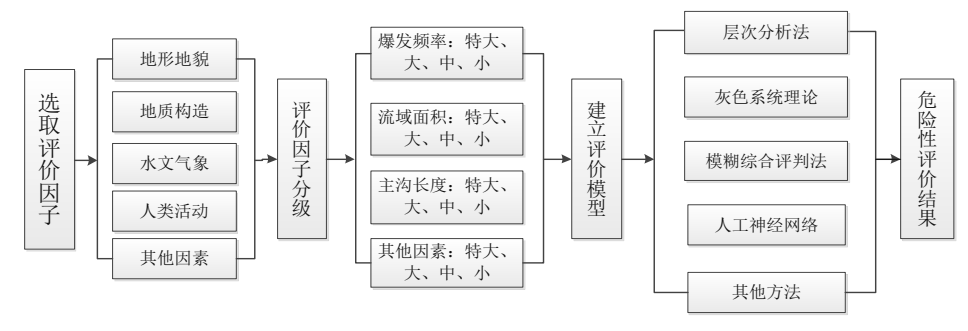

图 2 基于统计学的泥石流危险性评价方法流程图 
Risk Analysis and Crisis Response in Big Data Era (RAC-16)

表 1 典型研究泥石流危险性评价中选择的评价因子

\begin{tabular}{ll}
\hline 研究者 & 选取的评价因子 \\
\hline Takahashi[19] & 沟床坡度、积水面积、堆积层厚度、地质条件、汇水条件等 \\
林炳森等[27] & 岩性、断层长度、崩塌地面积、边坡坡度及坡向、沟床平均坡度、集水区面积、形 \\
& 状系数及植被情况 \\
杨明德[28] & 崩塌规模、岩性、流域坡度、土石堆积粒径、植被情况等 \\
谭炳炎[23] & 地貌因素、河沟因素和地质因素所包含的 15 项项目 \\
刘希林等[26] & 主要因子: 一次泥石流 (可能) 最大冲出量和发生频率, 次要因子包括流域面积、 \\
& 主沟长度等 8 项。 \\
泥石流灾害防治工程勘 & 流域形态特征、地质条件等 15 项进行泥石流沟易发程度数量化评分因子 \\
查规范[29] & \\
\hline
\end{tabular}

目前国内较成熟的方法有层次分析法、灰色系统评价 法、模糊综合评判法、人工神经网络法等[14] (表2)。 此外还有基于信息熵[42, 43]、突变理论[44]等的 评价方法。基于统计学的泥石流危险性评价方法一般 是定性与定量相结合, 在评价因子的选取和确定其权 重上都存在一定的主观性, 方法的可操作性较强, 是 目前应用比较广泛的一类泥石流危险性评价方法。

\section{2 基于数值模拟的泥石流危险性评价}

从泥石流的运动机理和力学特性进行泥石流数值模
拟, 可近似再现泥石流运动冲淤过程, 定量描述泥石 流的流速、流深、冲击力和堆积状况[45], 为防灾减 灾提供技术支持, 是目前常用的泥石流危险性评价方 法。

数值模拟的方法是根据质量守恒、能量守恒和动 量守恒原理, 建立动力学模型, 结合计算机技术, 运 用数值方法求解动力学模型, 得到泥石流的流速、流 深等相关参数, 根据参数结果进行泥石流危险性分区 (图3)。

表 2 典型统计学方面的泥石流危险性评价模型

\begin{tabular}{|c|c|c|c|}
\hline 评估模型 & 方法简介 & 主要研究者 & 优缺点评价 \\
\hline $\begin{array}{l}\text { 层次分析 } \\
\text { 法 }\end{array}$ & $\begin{array}{l}\text { 利用层次分析法确定各评价因子的权重 } \\
\text { 值, 然后构建泥石流危险度评价模型 } \\
R=\sum_{c i}^{n}\left(B_{i} * W_{c i}\right)\left(\mathrm{R} \text { 为危险性值; } \mathrm{B}_{\mathrm{i}}\right. \\
\text { 为各评捛因子的定量打分; } \mathrm{W}_{\mathrm{ci}} \text { 为各因子 } \\
\text { 权重 })\end{array}$ & $\begin{array}{l}\text { 朱静[30] } \\
\text { 铁永波[31] }\end{array}$ & $\begin{array}{l}\text { 具有较高的逻辑性、系统性、简洁性和 } \\
\text { 实用性的特点, 适用于目标结构复杂且 } \\
\text { 缺乏必要的数据时使用, 是半定性、半 } \\
\text { 定量问题转化为定量问题的行之有效 } \\
\text { 的方法。 } \\
\text { 评价因子的权重基于专家打分法获得, } \\
\text { 主观性较强, 容易出现误差; }\end{array}$ \\
\hline 灰色系统 & 泥石流危险性评价时, 运用灰色关联度计 & 刘希林, 唐川[26] & 较好的确定主次因子之间关系的密切 \\
\hline 理论 & $\begin{array}{l}\text { 算方法确定选取的各个影响因子的权重 } \\
\text { 值, 然后建立相应的评价模型 }{ }^{[30] 。}\end{array}$ & 张春山[33] & $\begin{array}{l}\text { 程度, 算法思路清哳, 对数据要求较低, } \\
\text { 易于操作。 } \\
\text { 该评价方法在我国得到了广泛的应用 } \\
\text { 和验证, 且有较大的影响力。 }\end{array}$ \\
\hline 模糊综合 & 应用模糊数学的思想和方法, 透过隶属度 & 孙广仁等[35] & 对于不精确或者资料不充足的问题具 \\
\hline 评判法 & $\begin{array}{l}\text { 的表达, 将主观性及不确定性的事物进行 } \\
\text { 综合评判的一种数学方法 }{ }^{[32]} \text { 。 }\end{array}$ & 刘丽等[36] & $\begin{array}{l}\text { 有效力。 } \\
\text { 计算过程复杂, 计算过程中运用取大取 } \\
\text { 小算法时极容易造成信息的丢失, 从而 } \\
\text { 影响模型的准确性。 }\end{array}$ \\
\hline 人工神经 & 神经网络法建立是以泥石流危险性评价 & 刘涌江等[37] & 结构简单, 易于理解。客观性较好, 能 \\
\hline 网络法 & $\begin{array}{l}\text { 因子为输入层, 危险等级分类为输出的拓 } \\
\text { 扑结构,通过优化算法, 反复调整各层神经 } \\
\text { 元的权值直至最终降低实际输出与期望 } \\
\text { 输出的误差, 从而对泥石流样本点危险性 } \\
\text { 做出评判。 }\end{array}$ & $\begin{array}{l}\text { 赵源等[38] } \\
\text { 黄双等[39]。 } \\
\text { 李秀珍等[40] }\end{array}$ & $\begin{array}{l}\text { 很好的避免主观赋权引起的误差, 可靠 } \\
\text { 性和科学性高; } \\
\text { 评价因子数量较多时, 计算量较大; 人 } \\
\text { 工神经网络对于输入层的优化存在着 } \\
\text { 黑箱操作问题, 很难解释和验证其反演 } \\
\text { 结果[41]。 }\end{array}$ \\
\hline
\end{tabular}


Risk Analvsis and Crisis Response in Bia Data Era (RAC-16)

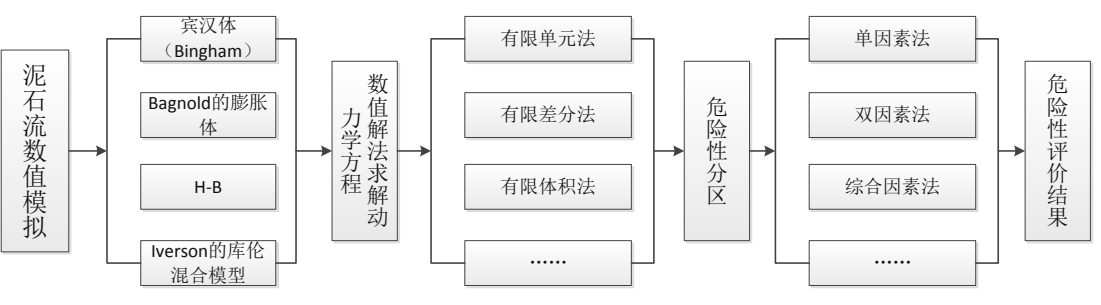

图 3 基于数值模拟的危险性评价方法流程图

美地质学家Johnson 和 Rahn 提出利用宾汉粘 性流模型解释泥石流现象, 第一次建立了泥石流运动 方程, 并计算出了泥石流的最大流速[46]。采用不同 的动力学模型和数值解法形成的不同的泥石流数值 软件, 目前某些计算软件已经应用到一些政府部门和 科研单位, 如瑞士的DFEM、加拿大的DAN-3D和我 国的Particle模型, 还有一些商业软件如FLO-2D (美) 和CFX (ANSYS 公司)。

国内数值模拟泥石流危险性的工作还处于起步 阶段, 唐川等运用隐式剖开算子法求解二维非恒定流 方程, 用计算机模拟出云南怒江芭蕉河流域泥石流流 速和泥深分布图, 并进行堆积区危险性分区, 与现场 调查较为吻合[45]。罗元华采用考虑侵蚀因素的控制 方程, 进行泥石流堆积区数值模拟[47]。张鹏等通过 野外实测数据, 运用FLO-2D软件对武都地区的清水 沟、嘴子沟进行数值模拟, 结合GIS分析可能淤积范 围, 与实际灾情威胁范围大致相符 [48]。
通过泥石流数值模拟得到泥石流流速和泥深等 参数数值, 流速反映泥石流的冲击破坏力, 泥深反映 泥石流的淤埋破坏力, 一般以流速和泥深作为泥石流 危险性分区的两个重要指标, 分区方法大致有 3 种: 基于流速或泥深的单因素分区方法、基于流速和泥深 的双因素组合分区法及综合考虑流速和泥深的综合 因素分区法[49]。综合因素分区法既考虑到了泥石流 的冲击性, 又考虑到了泥石流的淤埋能力, 是较为有 效的综合方法。

韦方强首次将流速和泥深两因素综合, 建立危险 性的动量分区法[50]。胡凯衡[51]等则将流速和泥深 两因素建立了泥石流危险性的动能分区法, 利用等方 差法进行危险区分级。Jakob和Hungr在对委内瑞拉沿 海1999年群发的泥石流进行强度划分时, 不仅考虑了 最大泥深对危险性的影响, 还提出结合最大泥深与最 大流速的乘积共同参与泥石流强度划分 [52]。

泥石流数值模拟相比定点观测和试验成本低, 重

表 3 当前主流的泥石流数值模拟模型

\begin{tabular}{ll}
\hline 模型 & 模型简介 \\
\hline FLO-2D & 基于流体连续运动原理的二维模拟软件, 可模拟流速、泥深、冲击力等参数, 数据可用于 GIS 平台。 \\
MassMov2D & 基于 PCRaster 的开源软件, 结果输出类型多样 (可地图、文章和图形) \\
DAN3D & 基于半经验方法和等效流体概念进行泥石流模拟, 可选择不同的流变参数组合。 \\
RAMMS & 基于连续流体介质的一维模型, 其阻力主要为粘滞力。 \\
AschFlow & 基于流体连续运动原理, 通过程序的编写采用多种流变参数, 可模拟流速、堆积体厚度和危险范围。 \\
\hline
\end{tabular}

表4 双因素组合分区和综合因素分区法

\begin{tabular}{|c|c|c|c|c|}
\hline 研究者 & 极高危险 & 高危险 & 中度危险 & 轻度危险 \\
\hline \multirow{2}{*}{ 唐川等[53] } & $\mathrm{v}>5$ & $2<\mathrm{v}<5$ & $1<\mathrm{v}<2$ & $\mathrm{v}<1$ \\
\hline & $h>3$ & $1<\mathrm{h}<3$ & $0.5<\mathrm{h}<1$ & $\mathrm{~h}<0.5$ \\
\hline \multirow{2}{*}{ 唐川等[45] } & $\mathrm{v}>4$ & $2<\mathrm{v}<4$ & $1<\mathrm{v}<2$ & $\mathrm{~V}<1$ \\
\hline & $\mathrm{h}>2$ & $1<\mathrm{h}<2$ & $0.5<\mathrm{h}<1$ & $\mathrm{~h}<0.5$ \\
\hline 韦方强等 ${ }^{[50]}$ & - - & $\mathrm{\beta e} \mathrm{V}^{2} \geqslant 110.56$ & $18.22 \leqslant_{\beta \mathrm{Q}} \mathrm{v}^{2}<110.56$ & $\beta_{\mathrm{e}} \mathrm{V}^{2}<18.22$ \\
\hline \multirow{2}{*}{ Jakob等[52] } & 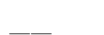 & $\mathrm{H}>1$ & $0.2<\mathrm{H}<1$ & $0.2<\mathrm{H}<1$ \\
\hline & & 或VH＞1 & 且 $0.2<\mathrm{VH}<1$ & 且 $V H<0.2$ \\
\hline
\end{tabular}


Risk Analysis and Crisis Response in Big Data Era (RAC-16)

复性强, 其成果具有坚实的理论依据, 近年来被广泛 应用到泥石流研究中。我国各大泥石流观测研究站的 建立为泥石流数值模拟提供了参数支持和验证资料。 但由于泥石流流体的复杂多变性, 现有的泥石流流体 模型仍然不能很好地概括和描述泥石流的动力学过 程, 泥石流流体模型的理论仍然有待进一步地完善。 随着数学模型的演进、计算机计算的进步和监测数据 的完善, 基于数值模拟的泥石流危险性评价将会再防 灾减灾中发挥更好的作用。

\section{3 近年来结合 $3 S$ 技术等的泥石流危险性评价}

科学技术的进步与发展给泥石流危险性评价研究也 带来了较大的便利和进步: 通过高精度RS影像, 可 快速获取灾害的相关数据, 弥补地面数据的不足, 减 少了野外工作量; GPS准确定位, 无人机实时快速航 拍, 实现动态微地貌和灾害数据的快速获取; 各种先 进监测仪器的研制和精度的提高, 为泥石流数据的完 备性和精度提供支持; GIS强大的数据存储、空间分 析和成图技术等功能成为数据处理的新方法, 节省了 大量的手工绘图耗费的人力物力。但相较于国外, 国 内利用GIS技术进行区域泥石流危险性分析还处于 发展阶段, 具有广阔的研究空间。

对于泥石流资料不完善的区域, 难以获得评价所 需的参数, 便可以通过对区域的地形地貌、地层岩性、 地质构造、降水、植被特点等基础背景资料的分析, 进行泥石流进行危险性评价和分区[54]。目前研究主 要用ArcGIS软件来进行。如陈晓清等利用Arcinfo作 为GIS平台, 分析实例区的地形、降水、地层、地质 构造、气温及地震烈度等因子, 进行了危险性区划, 可靠性较好 [55]。唐川等利用地形坡度、岩土体类型、 暴雨天数、地震烈度、土地利用和公路分布 5 个评价 指标, 得到了云南省泥石流危险性评价图[56]。2005 年李新坡等应用 GIS和BP神经网络方法, 根据云南省 31 年的降水数据和DEM数据进行云南省泥石流的危 险性评价和区划, 评价结果与其他方法的结果较为一 致[57]。王纯祥等基于GIS对日本水俣市宝川区的泥 石流进行二维数值模拟, 再现了泥石流传播和泛滥过 程, 与实际监测结果吻合[58]。Walsh等应用GIS对泥 石流形态特征进行了可视化。

\section{3 问题与展望}

泥石流影响因素的复杂性及不确定性, 流体的复杂 性, 使得对泥石流危险性的评价极为复杂, 需要从多 角度、多手段进行研究。虽然目前已经有多种评价方 法应用, 但仍没有统一的评价标准, 因此, 尝试多种
评价方法的研究对泥石流学科的发展有促进的意义。 但是, 目前的泥石流危险性评价还需要在某些方面进 行深入的探讨和研究:

(1) 评价因子的选取

基于统计学的泥石流危险性评价方法, 从野外调 查的结果出发, 选取某些评价因子, 通过数学模型如 层次分析法、灰色关联度法、模糊分析、人工神经网 络等, 将评价因子量化分级, 进而计算得出结论, 成 本低, 操作性强。但评价因子的选择目前没有统一的 标准, 因学者的观点、背景和掌握资料情况的不同而 不同, 得出的结果也就大相径庭, 这种掺有主观性的 方法可靠性和科学性不高, 结论令人难以信服。

（2）泥石流危险性评价方法研究

基于统计学的泥石流危险性评价方法作为半定 性半定量的方法, 具有一定的可操作性和实用性, 应 用广泛, 但科学性不足, 只能简单量化某条沟的危险 程度，且对同一条沟不同时间爆发的泥石流得到相同 的结果, 不能反映微地貌变化对于泥石流危险性的影 响。基于数值模拟的泥石流危险性评价方法从机理的 角度模拟泥石流的泥石流运动、演化、堆积、泛滥过 程, 能够给出明确的泥石流堆积泛滥范围和不同时刻 的速度分布及反映泥石流沟不同时期的变化, 但虽然 有比较多的动力学模型, 由于泥石流体的复杂多变 性, 目前仍没有一个动力学模型能很好的概括和描述 泥石流动力学过程, 作为较为前沿性的课题, 需要在 这方面进行深入研究。

（3）结合 $3 \mathrm{~S}$ 技术等的泥石流危险性评价将成为 一种趋势

高精度遥感影像、无人机、各种监测设备、GIS 等技术的进步为泥石流危险性评价提供了强有力的 数据和工具的支持。GIS以其强大的数据存储、空间 分析和成图技术等功能, 成为泥石流危险性评价方法 的一个强大的工具, 但受限于基础数据的精度和研究 者的专业能力。提高GIS制图的精度, 能更准确地进 行泥石流危险性评价, 将成为未来泥石流危险性评价 的重要的技术和方法。

\section{4 参考文献}

[1] 唐邦兴, 周必凡, 吴积善. 中国泥石流. 北京: 商务印 书馆, 2000: 375.

[2] 王礼先, 王志民. 山洪及泥石流灾害预报. 北京: 北京 林业出版社, 2001: 282.

[3] 罗元华. 论泥石流灾害风险评估方法. 中国矿业. 2000(06): 74-76.

[4] 周伟, 唐川, 周春花. 汶川震区暴雨泥石流激发雨量 特征. 水科学进展. 2012(05): 650-655.

[5] Tang C, Zhu J, Li W L, et al. Rainfall- triggered debris flows following the Wenchuan earthquake. Bulletin of 
Engineering Geology and the Environment. 2009, 68(2): 187-194

[6] 谢洪, 钟敦伦, 矫震, 等. 2008 年汶川地震重灾区的 泥石流. 山地学报. 2009(4): 501-509.

[7] 崔鹏, 韦方强, 何思明, 等. 5•12 汶川地震诱发的山 地灾害及减灾措施. 山地学报. 2008(03): 280-282.

[18] 唐得胜. 基于 FLO-2D 模型的不同频率泥石流数值模 拟研究. 成都理工大学, 2014.

[9] 余斌，杨永红，苏永超，等. 甘肃省舟曲 8.7 特大泥石 流调查研究. 工程地质学报. 2010(04): 437-444.

[10] 国务院公报. 关于加快发展现代保险服务业的若干意 http://www.csrc.gov.cn/pub/newsite/flb/flfg/xzfg 8248/20 1505/t20150507 276318.html 2014.8.10

[11] 唐邦兴, 章书成. 泥石流研究. 中国科学院院刊 1992(2): 119-123.

[12] 杜榕桓, 李鸿琏, 唐邦兴, 等. 三十年来的中国泥石 流研究. 自然灾害学报. 1995(01): 64-73.

[13] 刘希林, 张松林, 唐川. 沟谷泥石流危险度评价研究. 水土保持学报. 1993(02): 20-25.

[14] 杨鍂. 基于 $3 \mathrm{~S}$ 技术的汶川强震区潜在突发性泥石流 危险性区划及评价研究. 成都理工大学, 2012

[15] 魏永明, 谢又矛. 关联度分析法和模糊综合评判法在 泥石流沟谷危险度划分中的应用. 自然灾害学报. 1998 7(2): 107-117.

[16] 吴积善, 王成华. 山地灾害研究的发展态势与任务. 山地学报. 2006(05): 518-524

[17] 足立胜治, 德山九仁夫, 中筋章人. 泥石流危险度判 定的研究. 新砂防. 1997, 3(30): 7-16.

[18] 池谷浩, 王丽. 云仙水无川泥砂流失量的推算方法 水土保持科技情报. 1996, 30(4): 30-34.

[19] Takahashi. Estimation of potential debris flows and their hazardous zones: Soft countermeasures for a disaster. Journal of Natural Disaster Science. 1981, 3(1): 57-89.

[20] M J A, R. H P. Mobilization of debris flows. Zeitschrif fur Geomorphologie. 1970, s(9): 168-186.

[21] R H, Kovacs. G. S. Soil slumps and debris flows: prediction and protection Bulletin American Association of Engineering Geologists. Bulletin of the Association of Engineering Geologists. 1981, 13(1): 17-28.

[22] Fuchs S, Heiss K, Huebl J. Towards an empirical vulnerability function for use in debris flow risk assessment. Natural Hazards and Earth System Science. 2007, 7(5): 495-506.

[23] 谭炳炎. 泥石流沟严重程度的数量化综合评判. 铁道 学报. 1986(02): 74-82.

[24] 刘希林. 泥石流危险度判定的研究. 灾害学. 1988(03): $10-15$.

[25] 刘希林. 沟谷泥石流危险度计算公式的由来及其应用 实例，防灾减灾工程学报, 2010,30(3): 241-245.

[26] 刘希林, 唐川. 泥石流危险性评价. 北京: 科学出版 社, 1995: 91.

[27] Lin P S, Lin J Y, Hung J C, et al. Assessing debris-flow hazard in a watershed in Taiwan. Engineering Geology. 2002, 66(2): 295-313.

[28] 杨明德, 苏东青, 杨晔芬. 草嶺地區土石流潛勢調查 與評估. 中华水土保持学报. 2005, 36(3): 301-312.

[29] 中华人民共和国国土资源部. 泥石流灾害防治工程勘 察规范[Z]. 中国标准出版社, 2006 .

[30] 朱静. 泥石流沟判别与危险度评价研究. 干旱区地理. 1995(03): 63-71.

[31] 铁永波, 唐川. 层次分析法在单沟泥石流危险度评价 中的应用. 中国地质灾害与防治学报. 2006(04): 79-84.
[32] 汪月鹃. 汶川震区北川县暴雨泥石流危险性评价. 成 都理工大学, 2009.

[33] 张春山．北京地区泥石流灾害危险性评价．地质灾害 与环境保护. 1995(03): 33-40.

[34] 王虹萍. 结合层次分析法与模糊理论于土石流潜势评 估之研究一以陈有兰溪集水区为例. 逢甲大學, 2010.

[35] 孙广仁, 毕海良. 模糊数学综合评判法在泥石流沟判 别与危险度评价中的应用. 青海环境. 1997(02): 72-77.

[36] 刘丽, 王士革. 滑坡、泥石流区域危险度二级模糊综 合评判初探. 自然灾害学报. 1996(03): 53-61.

[37] 刘涌江, 胡厚田, 白志勇. 泥石流危险度评价的神经 网络法. 地质与勘探. 2001(02): 84-87.

[38] 赵源, 刘希林. 人工神经网络在泥石流风险评价中的 应用. 地质灾害与环境保护. 2005(02): 135-138.

[39] 黄双, 李广杰, 陈伟韦. 基于人工神经网络的泥石流 灾害危险性评价. 山西建筑. 2007(03): 1-2.

[40] 李秀珍, 孔纪名, 李朝风. 基于 Matlab 的 BP 神经网 络在泥石流危险性评价中的应用. 工程勘察. 2010(01): 47-50.

[41] Tian Y, Xu C, Chen J. Regional Risk Assessment of Earthquake-triggered Landslides. Journal of Risk Analysis and Crisis Response, 2015, 5(4): 234-245.

[42] 王钧，欧国强，杨顺，等. 地貌信息熵在地震后泥石 流危险性评价中的应用. 山地学报. 2013(01): 83-91.

[43] 陈宁，杨武年，杨釒金. 基于 GIS 的岷江映秀段泥石流 危险性评价. 测绘. 2012(01): 3-5.

[44] 徐黎明. 基于突变理论的乌东德水电站近坝区泥石流 风险评价与防治研究. 吉林大学, 2013 .

[45] 唐川, 周钜乾. 泥石流堆积扇危险度分区评价的数值 模拟研究. 灾害学. 1994, 9(4): 7-13.

[46] 夏添. 震区泥石流危险性评价及预警减灾系统研究. 成都理工大学, 2013.

[47] 罗元华. 泥石流堆积数值模拟及泥石流灾害风险评估 方法研究. 中国地质大学, 1998 .

[48] 张鹏, 马金珠, 舒和平, 等. 基于 FLO-2D 模型的泥 石流运动冲淤数值模拟. 兰州大学学报(自然科学版), 2014, (03): 363-368.

[49] 韦方强, 胡凯衡, J. L. Lopez. 泥石流危险性分区及 其在泥石流减灾中的应用. 中国地质灾害与防治学报. 2007(01): 23-27.

[50] 韦方强, 胡凯衡, J. L. Lopez, 等. 泥石流危险性动 量分区方法与应用. 科学通报. 2003(03): 298-301.

[51] 胡凯衡, 韦方强, 何易平, 等. 流团模型在泥石流危 险度分区中的应用. 山地学报. 2003(06): 726-730.

[52] Jakob D M, Hungr P O. Debris-flow Hazards and Related Phenomena. Springer Berlin Heidelberg, 2005.

[53] 唐川, 刘希林. 泥石流堆积泛滥区危险度的评价与应 用. 自然灾害学报 1993,2(4): 79-84

[54] Dikau R, Cavallin A, Jager S. Databases and GIS for landslide research in Europe. GEOMORPHOLOGY. 1996, 15(3-4): 227-239.

[55] 陈晓清, 谢洪. 基于 GIS 的山泥石流危险度区划研究. 土壤侵蚀与水土保持学报. 1999, 5(6): 46-50.

[56] 唐川, 朱大奎. 基于 GIS 技术的泥石流风险评价研究. 地理科学. 2002, 22(3): 300-304.

[57] 李新坡, 莫多闻. 应用 GIS 和神经网络方法进行泥石 流危险度评价的研究一以云南省为例. 水土保持研 究. 2005(04): 7-9.

[58] 王纯祥, 白世伟, 江崎哲郎, 等. 基于 GIS 泥石流二 维数值模拟, 岩土力学. 2007(07): 1359-1362. 